\title{
Access to Land and Development ${ }^{1}$
}

\author{
Alain de Janvry and Elisabeth Sadoulet \\ University of California at Berkeley
}

August 2005

Access to land, and the conditions under which it happens, play a fundamental role in economic development. This is because how the modes of access to land and the rules and conditions of access are set, as policy instruments, has the potential of increasing agricultural output and aggregate income growth, helping reduce poverty and inequality, improving environmental sustainability, and providing the basis for effective governance and securing peace. This potential role is, however, difficult to capture, and there are many cases of failure. History is indeed replete with serious conflicts over access to land and with instances of wasteful uses of the land, both privately and socially. Governments and development agencies have for this reason had to deal with the "land question" as an important item on their agendas (de Janvry et al., 2002). We explain in this note: (1) why access to land, and the conditions under which it is accessed and used, are important for economic development, (2) how different types of property rights can affect access and use, (3) what are different modes of access, and in particular the role of land markets, and (4) what are some of the policy implications to enhance how access to and use of the land can contribute to economic development. We stress in this note that access to land may be a difficult policy question, but that access will only translate into development if the harder question of influencing how it is used is effectively resolved.

\section{Importance of access to land for development}

Land is not only a factor of production, and as such a source of agricultural output and income, it is also an asset, and hence a source of wealth, prestige, and power. Because it is a natural asset, its use affects environmental sustainability or degradation. For these reasons, the link between access to land and development is quite multidimensional and complex, with many tradeoffs involved.

If land is to serve as an instrument for output and income growth, investments have to be made to improve its productivity. For this to happen, incentives have to be provided. Some of

\footnotetext{
${ }^{1}$ Prepared as an entry for the New Palgrave Dictionary of Economics, $2^{\text {nd }}$ edition, Palgrave Macmillan.
} 
these investments are short term, but many others are tied to the land for long periods of time. As a result, the security of access is a central policy question as it is necessary for these investments to be made. Security can be guaranteed through formal means such as titles and legal enforcement, but also through informal mechanisms such as community recognition and enforcement of rights. Whichever way it is achieved, what matters to induce investment is that security of access be credible (Deininger, 2003).

To result in output and income growth, access to land must not only be secure, it must also be accompanied by access to complementary inputs and occur in a context favorable to productive use of the land. Empirically well established complementary inputs include other types of natural capital such as water, working capital, and human capital. Access to land without these complementary inputs in the agricultural production function is not useful for development. In addition, the context where land is used affects its productivity. This includes institutions (such as credit, insurance, and product and factor markets with low transactions costs), public goods (such as infrastructure, market intelligence, research and extension, land registration, and contract enforcement mechanisms), and policies (macroeconomic and agricultural policies favorable to the activities in which the land is used). If complementary inputs and a favorable context for land use are not provided, it is quite evident that access to land will achieve little for output and income. Access to land is thus necessary but not sufficient. Providing what it takes beyond access to achieve income and growth -- complementary inputs and a favorable context -- can be highly demanding.

Secure access to land and to complementary inputs in a context that allows productive use can be a powerful instrument for poverty reduction. The family farm, with its labor cost advantage when there are transactions costs on labor markets and incomplete incentives to hired labor, can be particularly effective for this (Bardhan, 1984). Existence of an inverse relation between farm size and total factor productivity, derived from the labor cost advantage of the family farm, has been used as the empirical regularity justifying redistributive land reforms toward a family farm system. Access to even a small plot of land can be a source of security in the face of food market and labor market risks. Women's control over land can be a source of empowerment, helping them consolidate their decision-making status over household expenditures that will often favor children (Agarwal, 1994). 
Finally, as a good in limited supply, the distribution of access to land can have a powerful influence on social inclusion and local governance. More egalitarian access can be the basis for greater political participation, more respect for the rule of law, ability to raise local fiscal revenues from a land tax, and provide the basis for the consolidation of democracy (Binswanger, Deininger, and Feder, 1995). While these relations are far from direct, it is impossible to ignore the role that access to land plays in affecting these outcomes.

\section{Property rights over land}

The benefits that can be derived from access to land depend on the property rights that codify access and use. Property rights become increasingly complete as they allow to cumulate the following functions: entry, extraction, management, exclusion, and sale (Ostrom, 2002). Open access resources grant to all the rights of entry and extraction. They typically induce overextraction, leading to the "tragedy of the commons". Common property resources grant to members of a defined group, such as a community, the rights of entry, extraction, management, and exclusion of non-community members. This form of property right can result in socially optimal resource use if community members have the ability to cooperate in defining and enforcing rules for individual extraction and maintenance (Baland and Platteau, 1996). Public ownership with centralized management also gives leaders these same rights. Socially optimum resource use can be achieved if controls and incentives can be aligned between leaders and workers, which has historically proved to be difficult in agriculture, in spite of the multiplicity of attempts. Finally, individual or corporate property rights give owners the full bundle of rights, including that of rental and sale. Effectiveness of this form of property right in land use depends on existence of efficient land rental and sales markets, as well as ability to internalize externalities, achieve economies of scale, and access mechanisms for risk spreading. Common property resources with cooperation may be a superior form of property right when individual tenures are unable to fulfill these functions.

Whether property rights correspond to common property or to individual or corporate forms of tenure, there are desirable aspects of these rights that need to be achieved for access to be efficient. One is duration of the rights: long term investments require sustained access and clear specification of how rights are transferred to others. Inheritance rights are thus a fundamental aspect not only of access to land but also of land use. A second is precise 
demarcation of land boundaries and clear specification of rights. GIS-based land demarcation, land registries and record keeping of transactions, and adjudication of rights mechanisms are thus fundamental aspects of land management. A third is availability of conflict resolution mechanisms, where conflicts over access to land can be resolved through informal or formal procedures that are fair and expedient. Uncertain rights and unresolved conflicts over access rights are the norm more than the exception in developing countries, requiring major investments in regularizing these situations. Finally, property rights must be evolutive, with the ability of individualizing or consolidating rights as opportunities and needs emerge.

\section{Modes of access to land}

Under open access resources, entry is granted to all. Access to common property resources is usually given by birth right in a particular community. Clear demarcation of boundaries and clear determination of membership are important to permit the definition and enforcement of rules. Individual encroachment over public lands, and establishing adverse possession rights through occupation, is an important form of access where public lands remain plentiful. Finally, individual inheritance is also one of the most prevalent form of access to land, with eventually discriminatory rights due to primogeniture and to gender and kinship privileges in inheritance.

Access to land through rental markets is often constrained by insecurity of property rights, confining transactions to narrow circles of confidence (family, friends, social peer) and thus segmenting markets. While fixed rent contracts are first-best efficient, sharecropping contracts may be the most efficient way of accessing land when there are market failures on insurance, credit, and non-traded inputs such as management and supervision (Hayami and Otsuka, 1993). In general, the role of land rental markets as a mode of access to land for the poor has been under-appreciated in land policy and these markets have all too often been atrophied by misguided rent controls.

Finally, the land sales market should expectedly be the most effective way of providing access to land to the most efficient entrepreneurs. This may, however, not be the case, because these markets suffer from serious distortions that limit fulfilling this role. Land tends to be overpriced relative to its value in productive use due to its function as a store of wealth, speculation on land appreciation, tax advantages, use as collateral in accessing credit, and the status and 
power it conveys. Over-pricing implies that even full credit lines using the land as collateral will not be sufficient to allow access to land to poor people without subsidies.

\section{Access to land and development: policy implications}

In managing their "land question", most countries have experimented with some type of land reform program (Dorner, 1992). This includes land reforms that have used the threat of expropriation to induce extensively used large farms to modernize or sub-divide into smaller farms (Brazil). Other reforms have collectivized the land, either as state farms or as cooperatives. This has generally (Russia, Eastern Europe) been based on the belief in economies of scale in farming and the superior efficiency of centralized management. In other cases, as in Latin America, collective farms have been used to facilitate transitions between large haciendas and subsequent distribution of the land as individual tenures (Mexico, Peru, Chile). Finally, the inverse relation has been invoked in implementing redistributive land reforms that have established family farms out of former large farms (Taiwan, South Korea) or out of state farms or cooperatives (Albania, Bulgaria).

Because the land sales market should be the most effective way of codifying access to land, land reforms have recently taken the form of "market-assisted land reforms", with examples in Brazil, Colombia, and South Africa (Deininger, 2003). In this case, transactions occur between willing sellers and willing buyers, and subsidies are granted to the poor in addition to credit so they can afford purchases at market prices that are in excess of the productive value of the land. These interesting experiments are still in progress and in much need of evaluation

\section{Conclusion}

Access to land, and how land is accessed and used, is a fundamental instrument for successful development, both economically and socially. History shows both success stories and resounding failures. In general, making land into an effective tool for development requires more than policing access: access must be secure, combined with the use of complementary inputs, and achieved in a context of institutions, public goods, and policies that allow the sustainable competitiveness of beneficiaries. Many policies and programs have been put into place to attempt to achieve this goal, but complexity of the task explains why success requires 
extensive control and commitment (Warriner, 1969). A fundamental lesson derived from history of the "land question" is thus that, while reforming the pattern of access to land is difficult to achieve, far more difficult is to make access complete in the sense of securing the competitiveness of beneficiaries so they achieve income growth, poverty reduction, and sustainable use.

\section{References}

Agarwal, Bina. 1994. A Field of One's Own: Gender and Land Rights in South Asia. Cambridge University Press.

Baland, Jean-Marie, and Jean-Philippe Platteau. 1996. Halting Degradation of Natural Resources: Is There a Role for Rural Communities? Oxford University Press.

Bardhan, Pranab. 1984. Land, Labor, and Rural Poverty: Essays in Development Economics. New York: Columbia University Press.

Binswanger, Hans, Klaus Deininger, and Gershon Feder. 1995. "Power, Distortions, Revolt, and Reform in Agricultural Land Relations." In Handbook of Development Economics, Vol. 3B, J. Behrman and T. N. Srinivasan, eds. Amsterdam: North-Holland.

de Janvry, Alain, Gustavo Gordillo, Jean-Philippe Platteau, and Elisabeth Sadoulet. 2002. Access to Land, Rural Poverty, and Public Action. Oxford University Press.

Deininger, Klaus. 2003. Land Policies for Growth and Poverty Reduction. Washington D.C.: The World Bank.

Dorner, Peter. 1992. Latin American Land Reform in Theory and Practice: A Retrospective Analysis. Madison, WI: The University of Wisconsin Press.

Hayami, Yujiro, and Keiji Otsuka. 1993. The Economics of Contract Choice: An Agrarian Perspective. Oxford University Press.

Ostrom, Elinor. 2002. "The Puzzle of Counterproductive Property Rights Reforms: A Conceptual Analysis." In Access to Land, Rural Poverty, and Public Action, A. de Janvry et al., eds. Oxford University Press.

Warriner, Doreen. 1969. Land Reform in Principle and Practice. Oxford: Clarendon Press. 